\title{
CAPTURE
}

\section{PRODUCTION OF DOCUMENTARY FILM DRIVING AWARENESS}

\author{
Kosalalita Anggiyumna Ranangsari ${ }^{1}$ and Qiu Fuquan ${ }^{2}$ \\ ${ }^{1}$ Tung Fang Design University, Taiwan \\ 2 Tung Fang Design University, Taiwan \\ E-mail: kosalalita@gmail.com¹; dpa@mail.tf.edu.tw²
}

\begin{abstract}
The film "Driving Awareness" tells about the importance of driving according to the rules for mutual safety. This film uses a linear storyline and character flashback plot. The purpose of this paper is to describe the concept and visualization of the documentary film "Driving Awareness". The stages in designing the creation of the documentary film "Driving Awareness" start from the idea, preproduction, production, then post-production. In the idea stage, the idea of a film story is determined together with the team and then converted into a script for the film to be made into a storyboard to illustrate every scene in the film as well as a detailed storyline. The pre-production stage determines the position of each person in filmmaking, selecting players, determining locations, and scheduling filming activities. Production activities are carried out according to a predetermined schedule by recording images of each scene. The whole shot was edited to make a whole film work and add backsound, transition effects, and coloring.
\end{abstract}

Keywords: Film, documentary, driving, and awareness

\section{INTRODUCTION}

Film at this time is not a new thing and is very closely or familiar related to people's lives. Not only as a medium of entertainment in television or cinema shows, film is also a medium of communication between filmmakers and their viewers. The enthusiasm of the audience, both young and old, towards the latest or new film is very high. This gave rise to various types of unique film genres with varied ideas. One type of film that is popular in recent years is a short film. Many Indonesian young people are enthusiastic in searching, watching, and even making short films. This proves that today's young generation is able to work or to create in order to participate to advance the world of Indonesian cinema through the festival held by institutions both at domestic and abroad.

In the audio visual world, short film is one of a unique form of media. Its development has also increased rapidly with the development of social media and platforms to show their works, such as Youtube, Instagram, Vine, Facebook, and Vimeo. Nowdays, there are many awards about short films that make short film activists, most of whom are indie moviemakers, increasingly competing to show their creativity.

It just like films in general, short film has a variety of genres, one of which is documentary films. Documentary film is a genre that is easily accepted by the audience, because the ideas / concepts are taken from the problems of daily life, even almost everyone has experienced it. The 
film idea or concept used tends to be more conspicuous so that the audience more understands and captures the value of the film easily.

In creating this film, the writer focuses on designing short film with a simple concept. This simply refers to a linear storyline with one main problem that is also displayed in the flashback flow.

The choice of concept was based on the low awareness of the public about the importance of driving carefully. The problems chosen in the creation of this film also often appear in national news, even we ourselves have seen it directly. The design of this short film also only uses music as background to create an interesting atmosphere, while the character's voice is used to explain the narrative of his life in the film.

The process of finding ideas in the creation of a work can be by reading, seeing someone's life experience, witnessing interesting, unique, and rare events that occur in a residential environment, even from dream experiences. The idea is then developed into a theme which is then conducted research to find more complete data (Santoso, 2014). The idea of creating this work arises from problems that arise in everyday life.

Almost every daily news in the newspaper and television cannot be separated from the name of the deadly accident on the highway. This can be seen from the fatality rate of accidents in Indonesia which has increased compared to the previous year. Based on the National Police Traffic Police statistics, the number of accident victims reached 28,238 people in the period 31 December 2018 to 31 March 2019. Meanwhile, motorcycles were still the type of vehicle that contributed the most in traffic accidents (Dananjaya, 2019). This inspired the writer to take the story of someone who violated traffic rules into a documentary film. With this documentary film, it is hoped that it will raise public awareness about the importance of obeying with traffic regulations.

Based on the above explanation, the problem in the creation of this film can be formulated, namely, "How is the visualization of the concept of linear and flashback flow in the creation of the short film Driving Awareness?" The results of the creation of this work are expected to benefit for students and the broad audience or society about the values of motorbike safety. The benefits of creating this film include: this article can be a reference for the development of ideas and creativity in producing films that are simple, easy to understand, and interesting.

\section{LITERATURE REVIEW}

Film is a live picture, called a moving picture. The film is technically a collection of images arranged into one to form an image that can move. In general, films are often called 'cinema' or life pictures 


\section{CAPTURE}

that form an art as a representation of life, construction trends from the world of entertainment, and also business. Films are divided into several types of genres, including horror, action, drama, thriller, comedy, animation, fantasy, and romance.

Films are created by recordings of people and objects (including fantasy and imagination) using a camera, or some are made with animation. Filmmaking, or in the academic sphere commonly called film production, is the process of making a film, starting from a story idea, or initial concept, to writing a script, recording, editing, directing and final screening in front of an audience and then can produce a program that can be watched. Filmmaking exists and develops throughout the world in various economic, social and political cases, and uses various cinematographic technologies and techniques.

After the second revival of the international film era, various types of films emerged, including: 1) Feature Films / Fiction, with the genre of drama, action, comedy, thriller, horror, etc .; 2) Documentary Film; 3) Animated Film (both fiction and documentary animated films); 4) Film Noir, which is a cinematic term used to describe the style of Hollywood films that feature criminal dramas (the early 1940s to the late 1950s); 5) Avant-Garde Film-Art / Cinema; 6) Independent Films (indie films), long and short films with stories that do not follow the storyline mostly with experimental and controversial styles; and 7) Other types of films (company profile, advertisements, music videos, video art and experimental videos) (Dwi, 2015).

Type of documentary film, including:

1) Expository (documentary about a matter that is usually filled with narration, aims to provide information and education); 2) Observational (contains about the real life of a person or a community, where subjects document their own experiences through voice-over, sometimes even they themselves act as personal camera holders); 3) Fly-On-The-Wall (documentation that follows a family or community's daily trips for some time, also commonly called reality shows); 4) Interactive / Reflexive (documentation in which the writer / director becomes the main character and is often shown interacting with his environment to influence the audience's reaction); 5) Poetic / Avant-Grade (contains the director's creative exploration in everyday matters without a specific theme); 6) Drama-documentary (a documentation in which the director often dramatizes events that are re-enacted / dramatized reenactment); 7) Mockumentary (a type of documentation that parodies the conventional form of documentary film in general, or a particular event, sometimes even fictional events with the purpose of entertaining or satire); and 8) Personal (documentary film that is usually made with an ordinary video camera showing the 
maker who is speaking to an audience, with the aim of exchanging opinions) (Dwi, 2015).

Generally in the process of making films involving a large number of people, and takes a long time, ranging from a matter of months to several years to complete, even longer if problems arise during production. Along with technological developments, the number of cameras and sophisticated mobile phones with high-resolution cameras, now makes it easy for film lovers to make their own films. Based on this, the term indie movie comes as an independent film work outside the name of the film studio. Indie films are usually produced to participate in film festivals ranging from national to international (Teguh, 2015).

\section{CREATING METHOD}

The creation of documentary films uses the Artistic Research approach, namely research through creative work in art (penelitian melalui kerja kreatif dalam seni) (Guntur \& Sugihartono, 2015). This creative work focuses on creating documentary films with standardized stages in the field of audio-visual and broadcasting.

The process of creating this film consists of several steps, namely the process of preproduction, production, and post-production. This process step is in accordance with the concept of MAVIB (Multimedia Audio Visual and Broadcasting) explained by Rahardja, et al. (in Ruhyana, 2016), that "... the steps of the MAVIB production concept begin with preproduction, then production, and finally postproduction."

\section{Preproduction}

Before recording images in documentary filmmaking, first design of shooting techniques. Mulyanta and Leong (in Ruhyana, 2016) explain the steps that must be taken in planning including the preparation of concepts and designs, making flow diagrams, directory management, and material collection.

Pre-production is the stage of planning and preparation for production. According to Rahardja, et al. (in Ruhyana, 2016), there are several preproduction steps in the MAVIB production concept including ideas, synopsis, scenarios, time schedules, scripts, budgets, storyboards, casts and crews, locations, and properties and settings. Each work was carried out by a production team that had been divided into tasks, including the writer as the storyboard maker.

\section{Production}

Production is the process that most determines the success of the creation of a film. The shooting process is led by a director, the person who most responsible for the production process. People who take part in this process include the cameraman or DOP (director of Photography) who regulates light, color, and records images. Artistic that regulates the set, make up, wardrobe, etc. and the soundman who 


\section{CAPTURE}

records sound (Yani, 2016).

Production activities are carried out within the campus environment, according to the chosen theme. In addition, the production crews involved the campus students where the authors studied.

\section{Post-production}

After shooting is completed, the next stage is post-production, where video editing of the shooting is done. Video editing is done in order to obtain a complete and interesting video for the audience to enjoy. Some of the activities carried out in the video processing or editing process include: the arrangement of film, the making of cinematic look, adding music, editing narrator voice, giving transitions, and adding inserts (Ruhyana, 2016). Film editing in terms of its activities can be divided into 3 aspects, namely technique, skills, and art (Dancyger, 2011).

In terms of material quality, every footage that will be done in the editing process has several requirements that must be met, namely technical, aesthetic, and narrative elements (Mascelli, 1965). Aesthetic elements also need to be considered by combining the composition of the scene, the player's movement with the camera, lighting, costumes, setting the location of the scene and property (Unsur estetik pun perlu diperhatikan dengan memadukan komposisi adegan, gerakan pemain dengan kamera, pencahayaan, konstum, setting lokasi adegan dan properti)
(Sugihartono \& Wibawa, 2019). Provision of image effects is done to give the impression of a flashback. The final element that need to be considered is narrative, where recording a scene requires an understanding of the ability to tell through visual storytelling so that it can be conveyed to the audience. After the film editing process is completed, then continuing to the rendering process. Rendering is the process of changing a project file into a file that can be run on other media. The film produced was shown at a film festival held by a campus in Taiwan.

\section{DISCUSSION}

\subsection{Creating Process}

The author and the team were inspired to make a documentary about motorbike safety on the highway. The reason why the team chose this theme was because of the low level of public awareness about ebedience with traffic regulations for road safety. Often the selfishness of road users makes them not obey with applicable regulations, even ignoring personal or others safety. This ignorance triggers the frequent traffic accidents.

The stages carried out in the making of this film include:

\section{1). Preproduction}

The making of this film began with the formation of a division to facilitate each division of team work. Each division includes producer, director, scriptwriter, storyboard, make up artist, editor, cameraman, actor, 
and gaffer. Because the film made is a short film, the number of people involved in this activity is not much.

After that, there was a discussion to determine how the story line will be made into a film so that it will be easily accepted by the public. The manuscript was prepared based on the experience of students who like speeding on the highway. The selection of university student as a character is very suitable because it is considered that young people has a high spirit or burning soul. The ideas that have been compiled are then consulted with the supervisor lecturer to avoid the risks that may arise when the filmmaking process takes place, because the shooting of this film is done on the highway. The risk that may arise could be very large or high risk.

Site selection is done by sending two people to review the exact location for the shooting scene. After all is considered sufficient for filmmaking material, then the script is illustrated in the form of a storyboard complete with a location that become the background along the scene with the main character and supporting characters. The storyboard is made exactly the same as the chosen shooting technique.

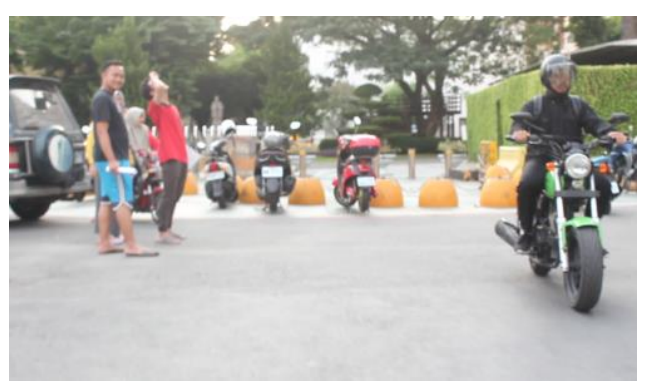

Figure 1. Survey activities in a parking area (Photo: Eghy Pasassung Datu, 2019)

Costume and property needs were prepared to support the film scene. The costume chosen for the main character seems simple according to the scope of a student, including a black jacket, black trousers, shoes, and backpack. The property used is not much, so in making this film does not require a large budget, because it only uses items that are used daily. The film's properties include a motorcycle, an electric bicycle and 2 helmets. The use of this electric bicycle is used by the supporting cast who acts as a person who is almost run over by the main character.

As a support devices in making this film, recording tools have been prepared such as 2 cameras, tripod, memory card, and clipboard. In the implementation, the author and colleagues did not use tools such as sound recorder and light. This is consistent with the consideration that the making of this film later in its editing is only filled with the sound of music and the voice of the main character as the narrator of the story. Even in the making, the scene is taken outdoors. So that taking pictures is enough 
to use sunlight as lighting.

$$
\text { Specifically regarding player }
$$

casting, the team agreed to choose the main character from the team members voluntarily, so that the casting division of the players did not need a budget to hire players. Two people from the team are enough to represent the entire plot.

2). Production

The film production stage is led by a director, the person who is in charge during the filming. The people involved in the shooting included cameramen, makeup and costume organizers, and clappers. Cameraman in charge of taking pictures, adjusting the light, and color. Cameraman must be proficient in camera mastery and lighting, so the resulting image quality will be satisfying. However, the camera aids are inadequate, causing the results of recording on the highway to be less stable and shake.

The taking pictures when the main character is driving is done with extra care so that no unwanted accidents occur. Lighting is also very considered in this process. In the morning, it was not possible to take pictures, so the team anticipated taking pictures in the afternoon. This is also due to the factor of the crowd of vehicles passing in the morning, so that it can cause traffic complexity. Morning is the densest time for people to start working and going to school.

Some scenes have problems because they have to equate one scene with another scene when shooting on the highway, because shooting is also done another day. The main factor is blazing or dim sunlight which is not the same every day greatly affects the process and the results of shooting.

Another thing that is rather difficult to do is shooting scenes of characters who almost hit other people on the highway. This is very difficult because shooting must be able to present a tense atmosphere during a collision session. For that reason, cameraman took pictures with close up techniques to display the main character and supporting figures who almost collided. However, there was no difficulty at all in shooting other scenes, both long shots and medium close ups.

\section{3). Post-production}

After the shooting process is finished, the last part in making this film is editing. Simply, the results of the shoot are tidied up and put together into a pleasant movie show. The editor reconstructs pieces of the picture taken by the cameraman and determines the dramatic side. In this film, the audio editing is only spiked with a simple backsound and the voice of the main character who tells the story, then the tense sound was added to a tense collision scene.

After the film production was finished, the next activity was reviewing the results of editing and re-shooting the scenes that are not quite right for shooting. The final result was considered interesting and 
worthy of being shown, then the film was shown at a film festival held by the campus.

\subsection{Art Work}

1). Specification

$\begin{array}{ll}\text { Title } & : \text { Driving Awareness } \\ \text { Year } & : 2019 \\ \text { Genre } & : \text { Documentary Film } \\ \text { Format } & : \text { mp4 } \\ \text { Duration } & : 10 \text { minutes } \\ \text { Synopsis } & :\end{array}$

Hamdan is a university student. He went to campus on a motorcycle. Before leaving home, he wore driving gear such as a jacket, gloves, mask and also a helmet. But there are bad behaviors that are not noticed. When riding on the road, he violates traffic rules. Sometimes he plays his cellphone, doesn't stop at a red light, and rides a motorcycle at a speed above normal. Because of that he almost crashed into another driver.

\section{2). Description of Work}

This short film has a total duration of 10 minutes, including the opening video, opening title, credit title, and guidance on procedures before driving. The editor does not include the behind the scene at the end of the film and replaces it with a guidance before driving properly. This guide appears together with the credit title to save time duration. At the end of the film, the editor uses the fade out transition and displays the opening title, followed by a video guide that uses the dissolve transition and the fade transition which raises the name of the teammates study program. The meaning implicit in this film is the importance of orderly driving for the safety of oneself and others. Description of the film can be presented per act as follows.

\section{Act 1 (Beginning)}

At the beginning of the film's opening, the atmosphere of the entrance gate of the Tungfang Design University campus, where the campus of the character is being studied as an international student from Indonesia.

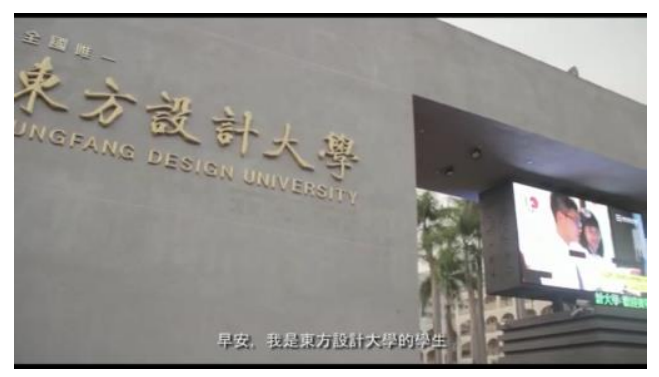

Figure 2. The atmosphere of the college (Source: Film Driving Awareness, 2019, timecode: 00.00.20)

The next scene shows the location of the character's residence in the dormitory. Shows showing a sleeping character and then his cell phone flaring indicating an alarm is ringing. Then the figure gets up and turns off the cellphone alarm,after that the character gets ready to take a shower.

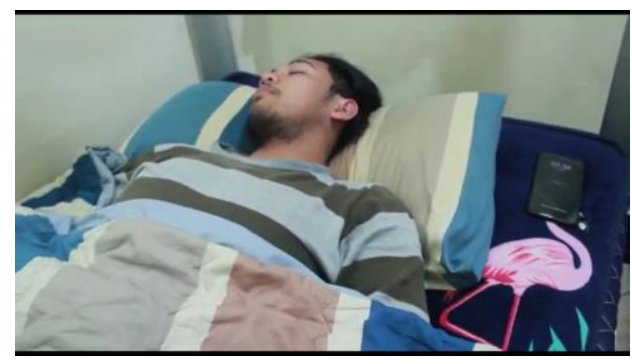




\section{CAPTURE}

Figure 3. Figure awakened by an alarm sound (Source: Film Driving Awareness, 2019, timecode: 00.00.34)

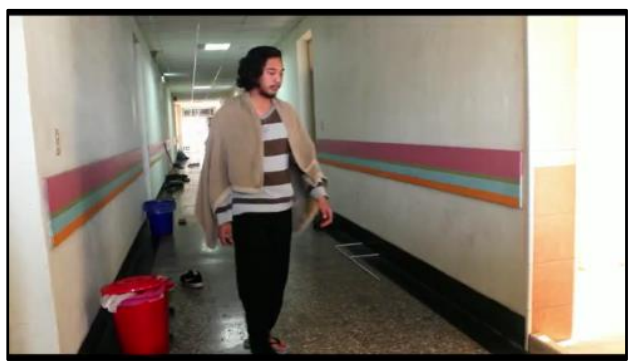

Figure 4. Figure goes to the bathroom (Source: Film Driving Awareness, 2019, timecode: 00.01.20)

After bathing, the character changes clothes and ties the rubber to his hair. Before going out of the dormitory, the character did not forget the figure wearing a jacket and shoes.

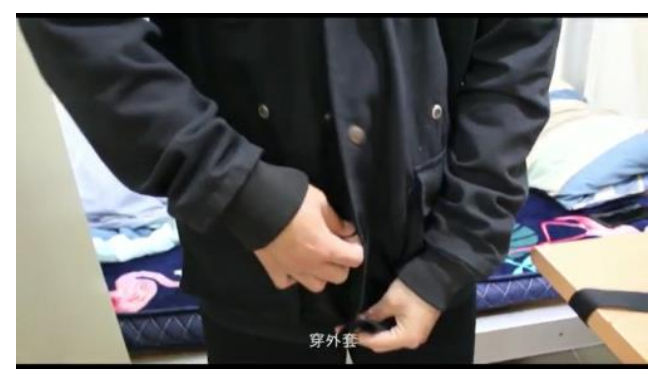

Figure 5. Figure wearing a jacket (Source: Film Driving Awareness, 2019, timecode: 00.01.50)

When he arrived at the motorcycle parking lot, he checked the condition of the motorcycle, especially the front and back tires. When he considered all in good condition, then he rode a motorcycle and wore a helmet before advancing his motorcycle.

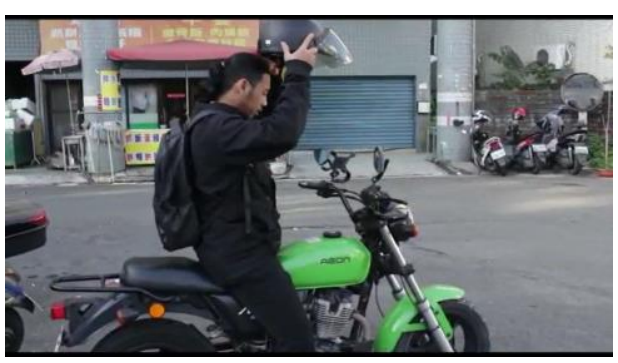

Figure 6. Figure wearing a helmet

(Source: Film Driving Awareness, 2019, timecode: 00.01.50)

\section{Act 2 (Middle)}

In this round the source of the problem starts to emerge or it can be called the beginning of a conflict with a character. While driving, he found a message from one of his friends. Then without fear he replied to the message with his left hand, while his right hand held the handlebar of his motorcycle.

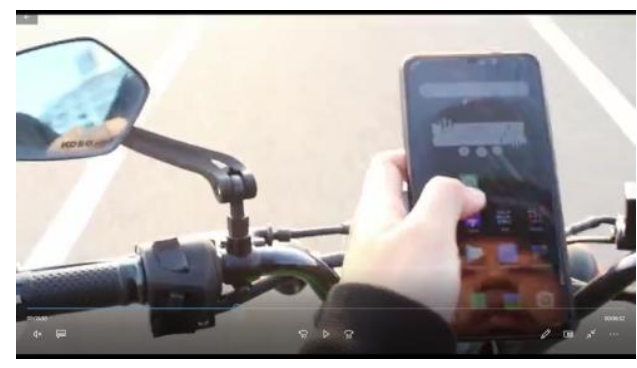

Figure 7. Figure replies to message when driving (Source: Film Driving Awareness, 2019, timecode: 00.03.30)

Because it is considered to take a long time to wait for the green light at a crossroad, then the character takes steps to break through the traffic. The character also advances his vehicle above the normal speed limit. Unexpectedly from the opposite direction a motorbike rider also wanted to cross the road, so that at the same time a character and another rider almost collided 
with each other.

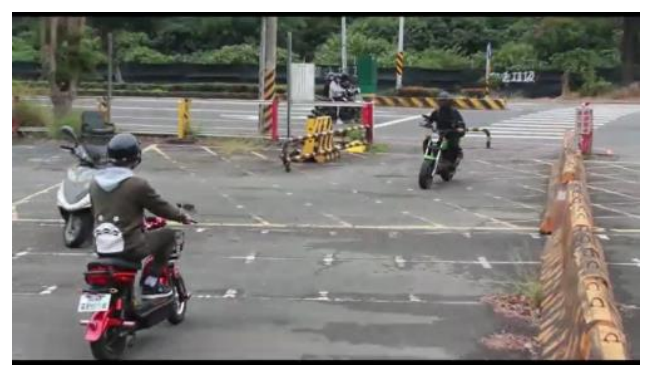

Figure 8. Seconds before the characters almost collide

(Source: Film Driving Awareness, 2019, timecode: 00.04.11)

\section{Act 3 (End)}

In this round the characters seem to ignore the events that have passed when almost colliding with another person. The character enters the class and is about to sit behind his classmate. However, the character's steps stopped and his eyes fixed on the news that was being watched by his friend.

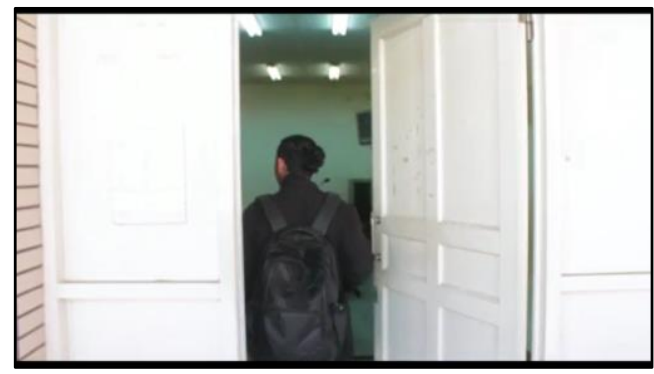

Figure 9. Figure entering the class (Source: Film Driving Awareness, 2019, timecode: 00.06.10)

The camera's point of view focuses on the news show, then the character remembers a past event. Then the change of scene began with the fade-in transition and shows footage of characters speeding on the highway and the events of characters that almost collide with others. In this trailer, the editor adjusts the color settings on the video and converts them to orange colors. This change of color signifies that this is the main conflict of the characters with the flashback plot.

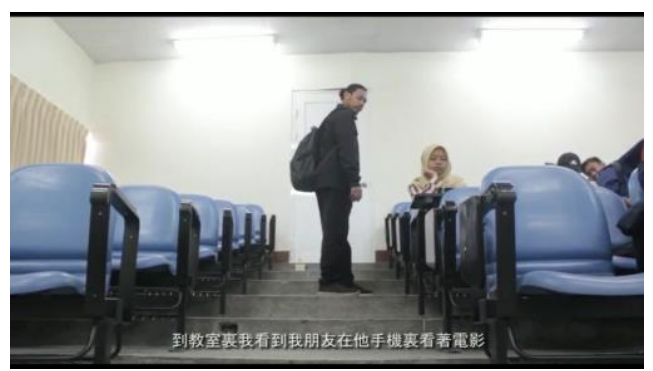

Figure 10. Figure coming to see the video (Source: Film Driving Awareness, 2019, timecode: 00.06.20)

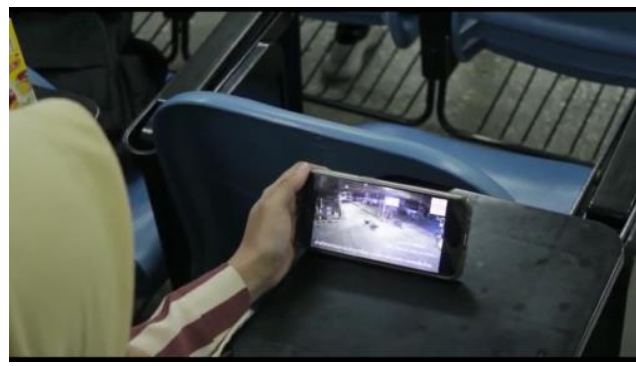

Figure 11. Friends of characters watching the news (Source: Film Driving Awareness, 2019, timecode: 00.06.36)

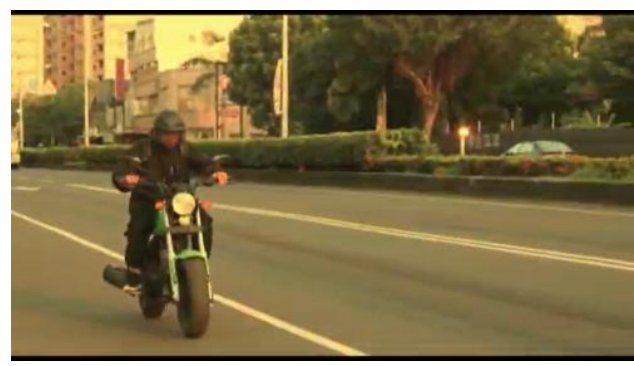

Figure 12. Flashback of character when speeding on the highway

(Source: Film Driving Awareness, 2019, timecode: 00.06.42)

After the flashback conflict trailer appears, it is connected with the scene of the character in the class with a pose where the character has recalled a past event. The previous trailer used the fade out transition 


\section{CAPTURE}

to combine with different scenes.

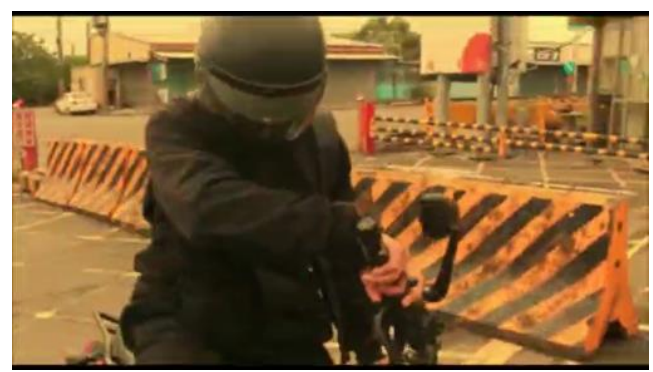

Figure 13. Flashback of a character who almost hit another road user

(Source: Film Driving Awareness, 2019, timecode: 00.06.45)

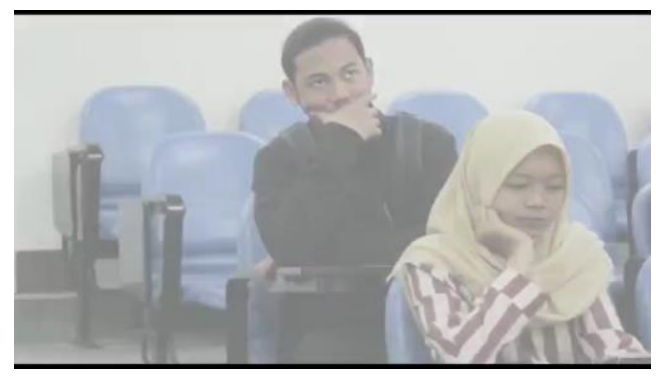

Figure 14. Figure has recalled past events (Source: Film Driving Awareness, 2019, timecode: 00.06.47)

At the end of the story the film closed with a conclusion that the character has realized his mistake and intends to change his bad habits on the highway. The film is connected with scenes of characters who want to go home and head to the parking lot.

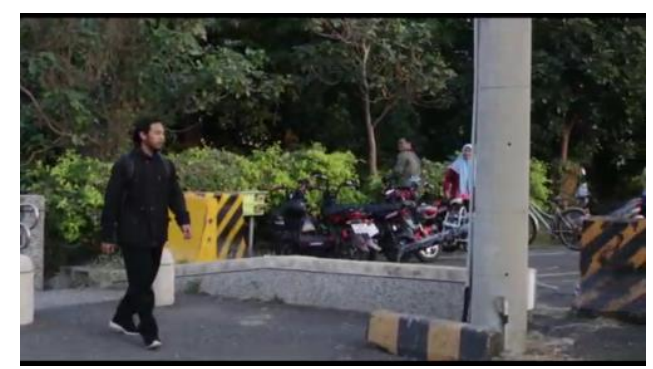

Figure 15. Figure goes to the school parking lot (Source: Film Driving Awareness, 2019, timecode: 00.07.25)

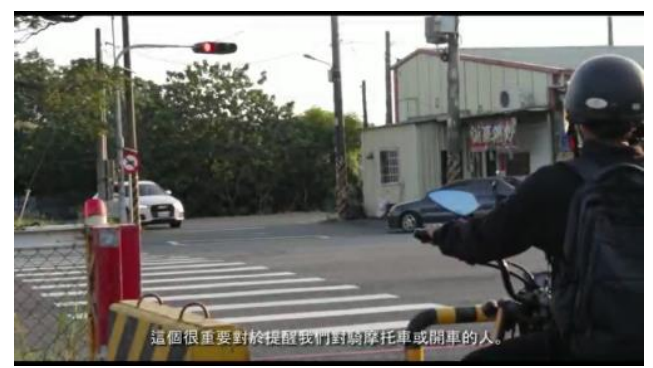

Figure 16. Figures rides obey the rules (Source: Film Driving Awareness, 2019, timecode: 00.08.22)

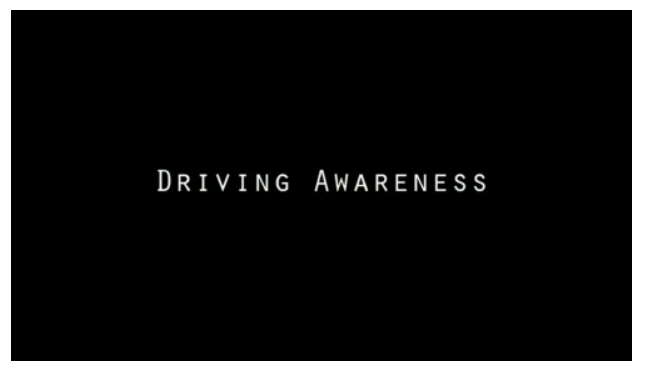

Figure 17. Display the title at the end of the show (Source: Film Driving Awareness, 2019, timecode: 00.08.40)

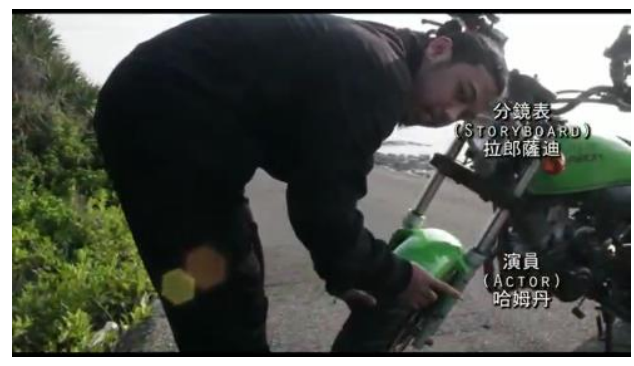

Figure 18. Credit title and right procedures before driving

(Source: Film Driving Awareness, 2019, timecode: 00.09.09)

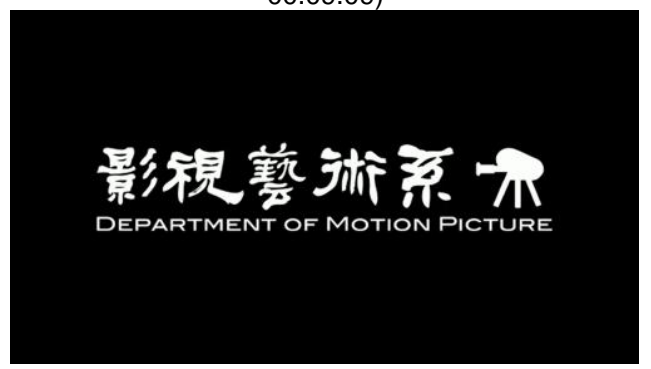

Figure 19. Name of departement as closing credit title

(Source: Film Driving Awareness, 2019, timecode: 00.09.50)

The scene continues with the location of the last scene at the crossroad. 
Taking this picture cameraman uses over shoulder techniques. The movie display shows the traffic light that is currently on. When the color of the lights turns into green, then a character advances his vehicle.

\section{CONCLUSION}

The existence of film in the midst of community life provides certain functions in transmitting a message from the filmmaker to a wide audience. From the discussion above it can be concluded that:

1) The concept of creating a "driving awareness" short film using a simple storyline taken from everyday life. In this film there is a major plotline as the main storyline, followed by a flashback plot in which the characters remember events that are the main conflict of the story.

2) In the creation of the short film "Driving Awareness" uses 1 (one) main character, Hamdan, who acts as a university student. Hamdan's character is personified as someone who likes to break traffic signs and drive on a whim (bad attitude). The main storyline of this film is the result of the actions caused by the main character who threatens the safety of others on the highway.

The theme of this documentary film which is very simple and close to daily life, facilitates the message (education) implied in this film to be conveyed to the audience. The simplicity of the storyline and the closeness of the theme to everyday life make this documentary film easy to understand and interesting for the audience.

\section{REFERENCES}

Dananjaya, D. (2019). Angka Kecelakaan Tahun 2019, Truk dan Sepeda Motor Sering Terlibat. Kompas. https://otomotif.kompas.com/read/2 019/09/09/160200815/angkakecelakaan-tahun-2019-truk-dansepeda-motor-sering-terlibat

Dancyger, K. (2011). The Technique of Film and Video Editing: History, Theory, and Practice (Fifth Edition). Focal Press.

Dwi, N. (2015). Jenis-Jenis Film. http://nikendwi1995.blogspot.com

Guntur, \& Sugihartono, R. A. (2015). Metodologi Penelitian Artistik. ISI Press \& P3AI ISI Surakarta.

Mascelli, J. V. (1965). The Five C's of Cinematography: Motion Picture Filming Techniques. Silman James Press.

Ruhyana, Y. H. (2016). Video Dokumenter Proses Pembuatan Batik Tulis dan Cap di Rumah Batik Komar [Tesis]. UPI Bandung. http://repository.upi.edu/27639/6/S _SRP_1103898_Chapter3.pdf

Santoso, B. (2014). Penciptaan Program Dokumenter "Budayaku" episode "Abdi Dalem" dengan Gaya Expository [Tesis]. ISI Yogyakarta. http://digilib.isi.ac.id/191/1/BAB\%20 1\%20Bowo.pdf

Sugihartono, R. A., \& Wibawa, A. (2019). Editing: Film, Televisi, dan Animasi. Graha IImu.

Teguh. (2015). 5 Alat yang Membantu Membuat Film Pendek Sempurna. https://teguhdepok.wordpress.com

Yani, I. N. W. A. (2016). Contoh Membuat 


\section{CAPTURE}

Makalah tentang Perfilman.

http://ikenurwulanasriyani.blogspot.

com 